\title{
PRESTASI BELAJAR PADA REMAJA YANG MENGALAMI DISMENOREA PRIMER
}

\author{
Yuniar Ika Fajarini ${ }^{1}$, Detty Siti Nurdiati ${ }^{2}$, Retna Siwi Padmawati ${ }^{3}$
}

\begin{abstract}
Background: Primary dysmenorrhea occurs in approximately $50 \%$ of teenage girls and cause serious disruptions in the quality of life and daily activities. Primary dysmenorrhea makes teenagers difficult to concentrate in school which will decrease their academic achievement.
\end{abstract}

Objective: to investigate whether there is a correlation between Primary dysmenorrhea and academic achievement of students of SMP Islam Terpadu Pondok Pesantren Tahfidzul Qur'an (SMP IT PPTQ) Ibnu Abbas Klaten.

Method: This study is a case-control study through a quantitative approach and was supported with qualitative data. The research sample is 68 teenage girls of SMP IT PPTQ Ibnu Abbas Klaten who fulfilled the inclusion criteria. The cases groups are female students with low learning achievement, while the control group was female students with high learning achievement. The samples were taken using simple random sampling. Researcher used a structured questionnaire, interview and secondary data to collect the data. The data analysis was using descriptive and inferential analysis including bivariate analysis using chi-square test and multivariate analysis using logistic regression with $95 \%$ confidence intervals $(\mathrm{Cl})$ and a significance level of $p<0.05$.

Result and Discussion: The bivariate and multivariate analysis showed a significant correlation between primary dysmenorrhea and learning achievement. The possibility of finding girls with primary dysmenorrhea in the group of students who received a low learning achievement is 3 times larger than the group of students who received high learning achievement. Below-average intelligence is greater in the group of low-achieving students than the group of high-achieving students. There is a correlation between the variables of intelligence, stress level and frequency of dysmenorrhea and academic achievement. The variable of absences frequency not related to learning achievement.

Conclusion: There is correlation between primary dysmenorrhea and learning achievement $(p=0.026)$. This study indicates that women and their school should pay attention to their menstrual function and dysmenorrhea phenomenon.

Keywords: learning achievement, primary dysmenorrhea, teenage, menstrual disorder

\begin{abstract}
ABSTRAK
Latar Belakang: Dismenorea primer terjadi pada kurang lebih 50\% remaja putri dan menyebabkan gangguan yang serius dalam kualitas hidup serta aktivitas sehari-hari. Dismenorea primer menyebabkan remaja sulit berkonsentrasi di sekolah sehingga prestasi belajar berpotensi menurun.
\end{abstract}

Tujuan: Mengetahui hubungan dismenorea primer dengan prestasi belajar pada santriwati di SMP Islam Terpadu Pondok Pesantren Tahfidzul Qur'an (SMP IT PPTQ) Ibnu Abbas Kabupaten Klaten.

\footnotetext{
STIKES Duta Gama Klaten

2,3 Departemen Obstetri dan Ginekologi FKKMK UGM
} 
Metode: Desain penelitian ini adalah studi kasus kontrol melalui pendekatan kuantitatif dan didukung data kualitatif. Sampel penelitian yaitu 68 remaja putri SMP IT PPTQ Ibnu Abbas Kabupaten Klaten dengan kriteria inklusi yang telah ditentukan oleh peneliti. Pengumpulan data menggunakan kuesioner terstruktur, wawancara mendalam dan data sekunder. Analisis data menggunakan analisis deskriptif dan inferensial yang meliputi analisis bivariabel dengan menggunakan uji chi-square dan analisis multivariabel dengan menggunakan uji regresi logistik dengan 95\% confidence interval (CI) dan taraf signifikan p<0,05.

Hasil dan Pembahasan: Analisis bivariabel dan multivariabel menunjukkan adanya hubungan yang bermakna antara dismenorea primer dengan prestasi belajar. Kemungkinan menemukan siswi dengan dismenorea primer pada kelompok santriwati yang mendapat prestasi belajar rendah 3 kali lebih besar dibandingkan kelompok santriwati yang mendapat prestasi belajar tinggi. Intelegensi dibawah rata-rata lebih besar pada kelompok santriwati yang berprestasi belajar rendah dibandingkan dengan kelompok santriwati yang berprestasi belajar tinggi. Ada hubungan antara variabel intelegensi, tingkat stress dan frekuensi dismenorea dengan prestasi belajar. Variabel frekuensi absensi tidak berubungan dengan prestasi belajar.

Kesimpulan: Terdapat hubungan antara dismenorea primer dan prestasi belajar $(p=0.026)$. Studi ini menunjukkan bahwa wanita dan sekolah harus lebih banyak mempelajari dan memberikan pengetahuan tentang organ reproduksi dan fenomena menstruasi mereka.

Kata Kunci: prestasi belajar, dismenorea primer, remaja, gangguan menstruasi

\section{PENDAHULUAN}

Salah satu tanda wanita telah memasuki masa reproduksi adalah wanita mengalami menstruasi setiap bulan secara periodik. Peristiwa ini merupakan peristiwa alamiah dan lazim dialami oleh wanita sebagai tanda kesiapannya menjadi seorang ibu. banyak wanita yang mengalami gangguan pada menstruasinya, diantaranya adalah nyeri haid atau sering disebut dismenorea. ${ }^{1}$

Dismenorea adalah keluhan yang sangat sering dan dapat terjadi primer maupun sekunder, tetapi dismenorea primer terjadi lebih sering. ${ }^{1,2}$ Tanda dan gejalanya antara lain adalah nyeri abdomen bawah seperti kram dan nyeri pelvik yang menjalar sampai ke paha dan punggung tanpa adanya gambaran patologik pelvik. ${ }^{1,2,3}$ Dismenorea primer umumnya terjadi pada tahun-tahun pertama setelah menstruasi pertama atau menarche, biasanya terjadi dalam 6-12 bulan pertama setelah menarche setelah siklus ovulasi teratur ditentukan. Intensitas dismenorea bisa berkurang setelah hamil atau pada umur sekitar 30 tahun. ${ }^{2,3}$
Prevalensi dismenorea tertinggi terjadi pada gadis remaja, dengan perkiraan $20-90 \%$ tergantung dari metode pengukuran yang digunakan. Di AmerikaSerikat sekitar 15\% gadis remaja dilaporkan mengalami dismenorea berat dan merupakan penyebab tertinggi para gadis remaja tidak hadir di sekolahnya. ${ }^{3,5}$ Remaja yang mengalami dismenorea pada saat menstruasi membatasi aktivitas harian mereka khususnya aktivitas belajar di sekolah. Dismenorea akan mengakibatkan aktivitas belajar santriwati di sekolah terganggu, kualitas hidup menurun dan terkadang hal ini membuat mereka tidak masuk sekolah. Seorang santriwati yang mengalami dismenorea tidak dapat berkonsentrasi belajar dan motivasi belajar akan menurun karena dismenorea yang dirasakan pada saat proses belajar mengajar. ${ }^{4,6}$

SMP Islam Terpadu (IT) Ibnu Abbas adalah salah satu Pondok Pesantren favorit yang ada di Kabupaten Klaten dengan jumlah keseluruhan remaja putri (santriwati) 266 orang. Selain kegiatan kurikulum, kegiatan ekstrakurikuler yang harus diikuti santriwati antara lain: program 
tahfidz, halaqoh, dan kelas pemantapan Bahasa Arab. Rata-rata pembelajaran $>48$ jam selama satu minggu. Berdasarkan hasil studi pendahuluan ketidakhadiran santriwati di kelas disebabkan karena sakit dan alasan keluarga. Hampir setiap minggu ada santriwati putri yang meminta izin untuk pulang ke asrama atau pergi ke UKS pada saat jam pelajaran berlangsung karena rasa tidak nyaman saat menstruasi. Ketidakhadiran di kelas ini setidaknya santriwati kehilangan satu hari kegiatan belajar, bila lebih dari satu minggu akan berdampak pada prestasi belajar. Ketidakhadiran di kelas selama proses belajar serta tidak mengikuti ujian dikarenakan gejala dismenorea ini akan mempengaruhi prestasi belajar. ${ }^{8,9}$

Berdasarkan hasil studi pendahuluan jumlah santriwati SMP IT Ibnu Abbas Klaten yang menderita dismenorea primer adalah 189 santriwati dari 262 santriwati yang terkaji. Jumlah keseluruhan remaja putri (santriwati) di kelas VIII SMP IT Ibnu Abbas adalah 99 orang, yang mengalami dismenorea primer adalah 69 santriwati dan yang mempunyai prestasi belajar rendah adalah sebesar 35,4\% (35 orang) dari 99 santriwati yang terkaji. Dari uraian diatas perlu untuk diketahui hubungan antara kejadian dismenorea primer dampaknya pada prestasi belajar pada santriwati SMP IT Ibnu Abbas Klaten.

\section{METODE}

1. Desain Penelitian

Penelitian ini merupakan jenis penelitian observasional yang menggunakan rancangan case-control. Penelitian ini dilengkapi dengan pendekatan secara kualitatif yaitu dengan wawancara mendalam (indepth interview), yang bertujuan untuk menggali lebih dalam informasi lain yang dibutuhkan untuk mendukung penelitian ini.

2. Subjek Penelitian

a. Populasi penelitian: santriwati kelas VIII SMP Islam Terpadu Pondok Pesantren
Tahfidzul Qur'an Ibnu Abbas Kabupaten Klaten pada tahun ajaran 2014/2015.

b. Subjek penelitian: subjek dalam penelitian ini dibedakan menjadi 2 kelompok, yaitu kelompok kasus dan kontrol. Kelompok kasus yaitu kelompok santriwati kelas VIII dengan prestasi belajar yang rendah, sedangkan kelompok kontrol adalah santriwati kelas VIII dengan prestasi belajar tinggi.

c. Lokasi penelitian: penelitian ini dilakukan di SMP Islam Terpadu Pondok Pesantren Tahfidzul Qur'an Ibnu Abbas Kabupaten Klaten.

d. Pengambilan Sampel: sampel data kuantitatif diambil dari perhitungan besar sampel menggunakan bantuan software program sampel size determination in health studies sehingga didapatkan sampel berjumlah 34 kasus dan 34 kontrol, dari hasil data kuantitatif dipilih beberapa sampel untuk sampel data kualitatif untuk dilakukan wawancara mendalam yang berjumlah 8 orang ${ }^{12,13}$.

3. Instrumen Penelitian

Data kuantitatif dikumpulkan dengan menggunakan kuesioner tertutup dan data sekunder, sedangkan data kualitatif dikumpulkan dengan wawancara mendalam menggunakan panduan wawancara mendalam (indepth interview) serta alat bantu antara lain tape recorder, kamera dan buku untuk catatan lapangan.

4. Analisis Data

a. Data kuantitif dianalisis dengan uji statistik Chi Square $\left(\chi^{2}\right)$ dengan $\alpha=5 \%$ untuk melihat hubungan antara variabel bebas dan terikat. Selanjutnya dilakukan uji regresi logistic, untuk melihat hubungan antara variabel bebas dan terikat dengan mengikutsertakan variabel luar. Hal ini dilakukan untuk mengetahui apakah terdapat hubungan yang signifikan antara variabel-variabel tersebut. 
b. Data kualitatif dilakukan untuk memperkuat data kuantitatif dengan melakukan wawancara mendalam. Langkah-langkah yang dilakukan sebagai berikut: 1) mendengarkan ulang hasil rekaman sambil membuat transkrip wawancara; 2) mengelompokkan data; 3) menyajikan data dalam bentuk deskriptif, analisis konten dan mengambil kesimpulan.

\section{HASIL DAN PEMBAHASAN}

\section{Karakteristik Subjek Penelitian}

Karakteristik responden merupakan hasil pengelompokan responden penelitian yang berjumlah 68 orang, yang dirinci menurut karakteristik usia, tinggi badan, berat badan, Indeks Massa Tubuh (IMT), umur menarche, status ekonomi dan jarak tempat tinggal. Penelitian ini menggunakan perbandingan kelompok kasus dan kelompok kontrol 1:1. Sebagian besar responden mengalami dismenorea primer dan mengalami tingkat stres berat mempunyai prestasi belajar rendah. Sebagian besar responden kelompok kasus mempunyai intelegensia dibawah rata-rata. Presentasi frekuensi absensi siswa dibawah rata rata lebih besar daripada presentase frekuensi absensi siswa diatas rata rata, sehingga dapat disimpulkan bahwa frekuensi kehadiran siswa baik.

Tabel 1. Karakteristik Responden Berdasarkan Usia, Tinggi Badan, Berat Badan, IMT dan Usia Menarche, Status Ekonomi Dan Jarak Tempat Tinggal.

\begin{tabular}{|c|c|c|c|c|c|}
\hline \multirow{2}{*}{ No } & \multirow{2}{*}{ Karakteristik } & \multicolumn{2}{|c|}{ Kasus } & \multicolumn{2}{|c|}{ Kontrol } \\
\hline & & $\mathbf{n}$ & $\%$ & $\mathrm{n}$ & $\%$ \\
\hline \multirow[t]{5}{*}{1} & Usia & & & & \\
\hline & - 12 tahun & 3 & 9 & 2 & 6.9 \\
\hline & - 13 tahun & 13 & 39.4 & 15 & 44 \\
\hline & - 14 tahun & 17 & 49.6 & 13 & 38.4 \\
\hline & - 15 tahun & 1 & 2 & 4 & 10.7 \\
\hline \multirow[t]{4}{*}{2} & Tinggi badan & & & & \\
\hline & • $140-150 \mathrm{~cm}$ & 7 & 20 & 6 & 16.4 \\
\hline & • $151-160 \mathrm{~cm}$ & 20 & 60 & 21 & 61.6 \\
\hline & - $161-170 \mathrm{~cm}$ & 7 & 20 & 7 & 22 \\
\hline \multirow[t]{3}{*}{3} & Indeks massa tubuh (IMT) & & & & \\
\hline & - Kurus & 26 & 38 & 18 & 27 \\
\hline & - Normal & 42 & 62 & 50 & 73 \\
\hline \multirow[t]{5}{*}{4} & Usia menarche & & & & \\
\hline & - 12 tahun & 39 & 57.8 & 37 & 54.7 \\
\hline & - 13 tahun & 25 & 37 & 26 & 38.4 \\
\hline & - 14 tahun & 3 & 4 & 4 & 5.7 \\
\hline & - 15 tahun & 1 & 1,2 & 1 & 1.3 \\
\hline \multirow[t]{3}{*}{5} & Status Ekonomi & & & & \\
\hline & • Tinggi & 33 & 48 & 48 & 70,4 \\
\hline & - Rendah & 35 & 52 & 20 & 29,6 \\
\hline \multirow[t]{3}{*}{6} & Jarak tempat tinggal & & & & \\
\hline & • Jauh & 37 & 55 & 34 & 50,4 \\
\hline & - Dekat & 31 & 45 & 34 & 49,6 \\
\hline
\end{tabular}

Sumber: Data primer diolah 


\section{Hubungan antara dismenorea primer dengan prestasi belajar}

Tabel 2. Hubungan Antara Dismenorea Primer, tingkat stress, Intelegensia, Frekuensi dismenorea primer, Frekuensi absen dengan Prestasi Belajar

\begin{tabular}{|c|c|c|c|c|c|c|c|}
\hline & \multicolumn{4}{|c|}{ Prestasi belajar } & \multirow{3}{*}{$\mathbf{P}$} & \multirow{3}{*}{ OR } & \multirow{3}{*}{ Cl 95\% } \\
\hline & \multicolumn{2}{|c|}{ Rendah } & \multicolumn{2}{|c|}{ Tinggi } & & & \\
\hline & $\mathbf{n}$ & $\%$ & $\mathbf{n}$ & $\%$ & & & \\
\hline \multicolumn{8}{|l|}{ Dismenorea primer } \\
\hline - Dismenorea & 25 & 74 & 16 & 47 & $0.026^{*}$ & 3.12 & $1.01-9.87$ \\
\hline - Tidak Dismenorea(R) & 9 & 26 & 18 & 53 & & & \\
\hline \multicolumn{8}{|l|}{ Tingkat stress } \\
\hline - Berat & 29 & 85 & 20 & 59 & $0.015^{*}$ & 4.06 & $1.12-16.44$ \\
\hline - Ringan(R) & 5 & 15 & 14 & 41 & & & \\
\hline \multicolumn{8}{|l|}{ Intelegensia } \\
\hline$\bullet<112$ & 23 & 68 & 13 & 38 & $0.015^{*}$ & 3.37 & $1.11-10.34$ \\
\hline$\cdot \geq 112(R)$ & 11 & 32 & 21 & 62 & & & \\
\hline \multicolumn{8}{|l|}{ Frekuensi dismenorea } \\
\hline - Sering & 22 & 65 & 13 & 38 & $0.029 *$ & 2.96 & $1.10-7.90$ \\
\hline - Jarang $(\mathrm{R})$ & 12 & 35 & 21 & 62 & & & \\
\hline \multicolumn{8}{|l|}{ Frekuensi absensi } \\
\hline - Sering & 15 & 44 & 9 & 27 & 0.128 & 2.19 & $0.07-6.94$ \\
\hline - Jarang(R) & 19 & 56 & 25 & 74 & & & \\
\hline
\end{tabular}

Hasil uji statistik menunjukan terdapat hubungan yang bermakna antara dismenorea primer dengan prestasi belajar. Kemungkinan menemukan siswi dengan dismenorea primer pada kelompok siswa yang mendapat prestasi belajar rendah 3 kali lebih besar dibandingkan kelompok siswa yang mendapat prestasi belajar tinggi. Prestasi belajar rendah lebih banyak terjadi pada siswa yang mengalami dismenorea primer bila dibandingkan dengan siswa yang tidak mengalami dismenorea primer.

Hasil analisis hubungan variabel dismenorea primer dengan prestasi belajar sama dengan hasil penelitian yang pernah dilakukan oleh Tenkiretal., yaitu terdapat hubungan yang signifikan antara dismenorea primer dengan prestasi belajar. $^{8}$ Siswa yang mengalami dismenorea primer lebih sering tidak mengikuti kegiatan belajar, tidak dapat mengikuti ujian atau mendapat skor nilai lebih rendah. ${ }^{6}$
Hasil penelitian ini juga menguatkan hasil penelitian Tenkir et al., yang menemukan hubungan signifikan antara dismenorea primer dengan prestasi belajar dimana berhubungan dengan dampak gejala yang menyebabkan tingginya angka absensi di sekolah dan berkurangnya aktivitas $(p=0,02)^{8}$ Hasil penelitian ini juga sesuai dengan studi kualitatif oleh Ningsih et al. Yang mengungkapkan bahwa informan merasakan sakit pada daerah perut bagian bawah serta keluhan pusing saat menstruasi menyebabkan informan tidak bisa kosentrasi dan tidak bisa mengikuti kegiatan belajar dikelas. ${ }^{7}$

\section{Hubungan antara tingkat stress, intelegensia, frekuensi dismenorea dan frekuensi absen terhadap Prestasi Belajar}

Variabel tingkat stress, intelegensia dan frekuensi dismenorea primer menunjukan hubungan yang bermakna dengan prestasi 
belajar karena variabel memiliki nilai $p<0,05$. Variabel frekuensi absensi tidak menunjukan hubungan yang bermakna dengan nilai $p>0,05$.

Hasil analisis bivariabel antara variabel stres dengan prestasi belajar didapatkan adanya hubungan yang signifikan. Hasil ini sesuai dengan beberapa penelitian sebelumnya yang menunjukkan bahwa persaingan yang ketat dalam mengejar prestasi belajar dapat menyumbang terjadinya stres. Stres merupakan salah satu dampak dari perubahan sosial, dan perubahan tatanan hidup ${ }^{10,11,14}$. Hasil analisis antara variabel intelegensi dengan prestasi belajar terdapat hubungan yang signifikan dengan nilai $p<0,05$. Intelegensi berkaitan dengan kemampuan untuk pemecahan masalah, kemampuan untuk belajar dan kemampuan berfikir abstrak sehingga dapat menentukan individu dalam memecahkan masalah apakah cepat atau lambat. Hal ini sesuai dengan hasil analisis univariabel yang menunjukan intelegensi dengan tingkat dibawah rata-rata lebih banyak pada siswa dengan prestasi belajar rendah daripada kelompok siswa yang berprestasi tinggi. Secara teoritis intelegensi akan mempengaruhi prestasi belajar selain di pengaruhi juga oleh faktor-faktor lain ${ }^{8,9}$.

Frekuensi dismenorea yang sering terjadi akan menyebabkan gangguan belajar yang akan beresiko pada menurunnya prestasi belajar. ${ }^{15}$ Tidak adanya hubungan yang signifikan antara variabel frekuensi absensi dimungkinkan karena koping dan pembagian waktu para santriwati yang baik membuat prestasi belajar menjadi stabil walaupun santriwati pernah tidak masuk sekolah.

\section{Model regresi logistik pengaruh dismenorea primer dengan prestasi belajar melibatkan variabel tingkat stress, intelegensia dan frekuensi dismenorea.}

Pada analisis multivariat, variabel-variabel independen yang bermakna dengan prestasi belajar sebagai variabel dependennya. Hasil analisis multivariabel disajikan dalam beberapa model (model 1-5) seperti variabel dismenorea primer, tingkat stress, intelegensia dan frekuensi dismenorea (variabel yang memiliki $p$-value < $0,25)$. 
Tabel 3. Pengaruh Dismenorea, Tingkat Sress, Intelegensia, Frekuensi Dismenorea, dan Frekuensi Absen terhadap Prestasi Belajar

\begin{tabular}{|c|c|c|c|c|c|}
\hline & Model1 & Model2 & Model3 & Model4 & Model5 \\
\hline & $\begin{array}{c}\text { OR } \\
\text { Cl95\% }\end{array}$ & $\begin{array}{c}\text { OR } \\
\text { Cl95\% }\end{array}$ & $\begin{array}{c}\text { OR } \\
\text { Cl95\% }\end{array}$ & $\begin{array}{c}\text { OR } \\
\text { Cl95\% }\end{array}$ & $\begin{array}{c}\text { OR } \\
\text { Cl95\% }\end{array}$ \\
\hline $\begin{array}{l}\text { Dismenorea primer } \\
\text { - Dismenorea } \\
\text { - Tidak Dismenorea(R) }\end{array}$ & $\begin{array}{c}0.028^{*} \\
3.12 \\
1.13-8.63\end{array}$ & $\begin{array}{c}0.039 * \\
3.05 \\
1.05-8.80\end{array}$ & $\begin{array}{c}0.017^{*} \\
3.82 \\
1.26-11.54\end{array}$ & $\begin{array}{c}0.011^{*} \\
4.35 \\
1.39-13.55\end{array}$ & $\begin{array}{c}0.010^{*} \\
5.83 \\
1.52-22.25\end{array}$ \\
\hline $\begin{array}{l}\text { Tingkat stress } \\
\text { - Berat } \\
\text { - Ringan(R) }\end{array}$ & & $\begin{array}{c}0.025^{*} \\
3.96 \\
1.18-13.24\end{array}$ & & & $\begin{array}{c}0.010^{*} \\
6.21 \\
1.54-25.08\end{array}$ \\
\hline $\begin{array}{l}\text { Intelegensia } \\
\text { - Dibawah rata-rata } \\
\text { - Diatas rata-rata(R) }\end{array}$ & & & $\begin{array}{c}0.011^{*} \\
4.06 \\
1.38-11.93\end{array}$ & & $\begin{array}{c}0.020^{*} \\
4.46 \\
1.26-15.67\end{array}$ \\
\hline $\begin{array}{l}\text { Frekuensi dismenorea } \\
\text { - Sering } \\
\text { - Jarang }(\mathrm{R})\end{array}$ & & & & $\begin{array}{c}0.012^{*} \\
4.11 \\
1.36-12.43\end{array}$ & $\begin{array}{c}0.004^{*} \\
6.61 \\
1.82-23.91\end{array}$ \\
\hline $\mathrm{R2}$ & 0.05 & 0.11 & 0.12 & 0.13 & 0.29 \\
\hline Deviance & 89.21 & 83.73 & 82.12 & 82.28 & 67.33 \\
\hline$n$ & 68 & 68 & 68 & 68 & 68 \\
\hline
\end{tabular}

Tujuan membangun model dalam analisis regresi logistik adalah untuk menemukan model yang paling sesuai dalam menjelaskan hubungan dismenorea primer dengan prestasi belajar dan untuk membuktikan pula jika variabel dismenorea primer ditambahkan dengan variabel lain akan tetap menunjukkan hasil yang bermakna dan tidak mengalami perubahan OR yang signifikan. Hasil analisis multivariabel model 1-5 menunjukkan dismenorea primer mempunyai hubungan yang bermakna baik secara praktis dan statistik dengan prestasi belajar rendah pada siswa. Variabel tingkat stress, intelegensi, dan frekuensi dismenorea mempunyai hubungan yang signifikan dengan prestasi belajar pada siswa.

Pendekatan kualitatif dilakukan untuk mendukung data kuantitatif yang ada. Hasil dari wawancara tentang keluhan rasa sakit saat menstruasi adalah rasa sakit pada perut, kepala pusing, lemas dan perasaan ingin marah-marah.
Keadaan tersebut mengganggu saat pelaksanaan ujian. Hasil wawancara kepada 8 responden didapatkan dampak dari rasa sakit pada saat menstruasi adalah terpaksa izin meninggalkan pelajaran di kelas dan menurunkan kosentrasi belajar. Suasana asrama yang ramai, tidak ada tempat tenang untuk belajar dapat menyebabkan terganggunya proses belajar. Teman dan guru yang baik dapat membuat siswa merasa betah disekolah. Motivasi untuk mendapat prestasi belajar adalah untuk melanjutkan pendidikan di SMA Favorit kemudian Perguruan Tinggi Negeri. Penyebab stres pada siswa adalah suasana menjelang ujian dan hukuman yang dihadapi bila terlambat. Stres berat lebih banyak dialami oleh kelompok siswa yang berprestasi belajar rendah.

Pengetahuan tentang kejadian dismenorea primer pada remaja sangat penting. Wawancara mendalam dengan beberapa guru di SMP IT Ibnu Abbas didapatkan hasil bahwa pengetahuan tentang kesehatan reproduksi sudah pernah 
dijelaskan meski tidak mendetail pada mata pelajaran Ilmu Pengetahuan Alam dan pada mata pelajaran Pendidikan Konseling.Tetapi, tidak ada pelajaran tentang gangguan nyeri haid atau dismenorea primer. Kedepannya diharapkan sekolah dapat bekerjasama dengan pihakpihak terkait untuk mengadakan seminar atau pendidikan kesehatan mengenai dismenorea primer dan gangguan menstruasi lainnya yang berkaitan dengan kesehatan reproduksi sehingga para siswa dapat mengetahui dan dapat mengurangi tingkat keparahan dismenorea primer sehingga tidak mengganggu aktivitas sehari-hari khususnya aktivitas belajar di sekolah.

\section{KESIMPULAN DAN SARAN}

Penelitian ini memperlihatkan hubungan yang bermakna antara dismenorea primer dengan prestasi belajar siswi kelas VIII SMP IT Ibnu Abbas Klaten.

\section{DAFTAR PUSTAKA}

1. Hickey, M. \& Balen, A. 2003. Menstrual disorders in adolescence: investigation and management. Human reproduction update, 9(5): 493-504.

2. Van Rensburg, K. 2011. Managing dysmenorrhoea in the pharmacy: review. SA Pharmaceutical Journal, 78(1): 42-44.

3. French, L. 2005. Dysmenorrhea. American family physician, 71(2): 285-291.

4. Susan, P. 1996. Adolescent Kingston girls' school achievement: nutrition, health and social factors. Proceedings of the nutrition society, 55333-343. Harel, Z. 2002. A contemporary approach to dysmenorrhea in adolescents. Pediatric Drugs, 4(12): 797-805.

5. Harlow, S. D. \& Park, M. 1996. A longitudinal study of risk factors for the occurrence, duration and severity of menstrual cramps in a cohort of college women. BJOG: An International Journal of Obstetrics \& Gynaecology, 103(11): 1134-1142.

6. Holder, A. 2012. Dysmenorrhea in Emergency Medicine. Diunduh dari: http://emedicine. medscape. com/article/795677-overview, 2.
7. Ningsih, R., Setyowati, S. \& Rahmah, H. (2013) Efektivitas Paket Pereda Nyeri Pada Remaja Dengan Dismenore. Jurnal Keperawatan Indonesia, 16(2).

8. Tenkir, A., Fisseha, N. \& Ayele, B. 2002. Premenstrual Syndrome :Prevalence and Effect on Academic and Social Performances of Students in Jimma University, Ethiopia. Ethiop journal health Dev,17, pp. 181-188.

9. Sukmadinata, N. S. (2003) Landasan psikologi proses pendidikan:Remaja Rosdakarya.

10. Ushie, M., Emeka, J., Ononga, G. \& Owolabi, E. 2012. Influence of family structure on students' academic performance in Agege local government area, Lagos state, Nigeria. European Journal of Educational Studies, 4(2): 177-187.

11. Lee, L., Chen, P., Lee, K. \& Kaur, J. 2006. Menstruation among adolescent girls in Malaysia: a crosssectional school survey. Singapore medical journal, 47(10): 869-874.

12. Creswell, J. W. 2013. Research design: Qualitative, quantitative, and mixed methods approaches:Sage publications

13. Lemeshow, S., Jr.D.W., H., Klar, J. \& Lwanga, S. 1997. Besar Sampel dalam

14. Penelitian Kesehatan, Yogyakarta: Gajah Mada University Press.

15. Sastroamoro, S. \& Ismael, S. 2005. Dasar-Dasar Metodologi Penelitian Klinis, Jakarta: Dian Rakyat.

16. Lee, L., Chen, P., Lee, K. \& Kaur, J. 2006.Menstruation among adolescent girls in Malaysia: a crosssectional school survey. Singapore medical journal, 47(10): 869-874.

17. Sundell, G., Milsom, I. \& ANDERSCH, B. 1990. Factors influencing the prevalence and severity of dysmenorrhoea in young women. BJOG: An International Journal of Obstetrics \& Gynaecology, 97(7): 588-594.

18. Sharma, P., Sharma, A., Taneja, D. K. \& Saha, R. 2008. Problems related to menstruation and their effect on daily routine of students of a medical college in Delhi, India. Asia-Pacific Journal of Public Health.

19. Singh, A., Kiran, D., Singh, H., Nel, B., Singh, P. \& Tiwari, P. 2008. Prevalence and severity of dysmenorrhea: A problem related to menstruation, among first and second year female medical students. 